Goldschmidt 2021 Abstract

https://doi.org/10.7185/gold2021.7170

\section{Magnetic mineral diagenesis and associated biogeochemical processes in cold seepage and gas hydrate sites of the Guaymas Basin}

MYRIAM KARS ${ }^{1}$, LUCIE PASTOR ${ }^{2}$, CÉLINE BURIN ${ }^{3}$, YUKI MORONO ${ }^{4}$, LOUISE M.T. KOORNNEEF ${ }^{5}$, TOBIAS W HÖFIG $^{6}$, ANDREAS TESKE ${ }^{7}$, DANIEL LIZARRALDE ${ }^{8}$, IVANO AIELLO ${ }^{9}$, JEANINE ASH ${ }^{10}$, DIANA BOJANOVA ${ }^{11}$, MARTINE BUATIER $^{12}$, VIRGINIA P. EDGCOMB ${ }^{8}$, CHRISTOPHE GALERNE ${ }^{13}$, SWANNE GONTHARET ${ }^{14}$, VERENA B. HEUER ${ }^{15}$, SHIJUN JIANG ${ }^{16}$, JI-HOON KIM ${ }^{17}$, KATHIE MARSAGLIA ${ }^{18}$, NICOLETTE R MEYER ${ }^{19}$, FLORIAN NEUMANN ${ }^{20}$, RAQUEL NEGRETE ${ }^{20}$, MANET PEÑA-SALINAS ${ }^{21}$, LIGIA PEREZ CRUZ ${ }^{22}$, LIHUA RAN ${ }^{23}$, ARMELLE RIBOULLEAU ${ }^{24}$, JOHN SARAO ${ }^{25}$, FLORIAN SCHUBERT $^{26}$, S. KHOGENKUMAR SINGH ${ }^{27}$, JOANN STOCK $^{28}$, LAURENT TOFFIN ${ }^{3}$, WEI XIE ${ }^{29}$, SHUMEI XU ${ }^{30}$, TOSHIRO YAMANAKA ${ }^{31}$ AND GUANGCHAO ZHUANG ${ }^{32}$

${ }^{1}$ Kochi University

${ }^{2}$ Ifremer, centre de Brest, REM/EEP/LEP

${ }^{3}$ Ifremer

${ }^{4}$ JAMSTEC - Japan Agency for Marine-Earth Sciences and Technology

${ }^{5}$ University of Plymouth

${ }^{6}$ International Ocean Discovery Program, Texas A\&M University

${ }^{7}$ University of North Carolina

${ }^{8}$ Woods Hole Oceanographic Institution

${ }^{9}$ San Jose State University

${ }^{10}$ Rice University

${ }^{11}$ University of Southern California

${ }^{12}$ Université Bourgogne Franche-Comté

${ }^{13}$ GEOMAR Helmholtz Centre for Ocean Research

${ }^{14}$ Universite du Littoral-Côte d'Opale

${ }^{15}$ MARUM - Center for Marine Environmental Sciences

${ }^{16}$ Jinan University

${ }^{17}$ KIGAM

${ }^{18}$ California State University, Northridge

${ }^{19}$ Stanford University

${ }^{20} \mathrm{CICESE}$

${ }^{21}$ Universidad Autónoma de Baja California

${ }^{22}$ Universidad Nacional Autónoma de México

${ }^{23}$ Second Institute of Oceanography

${ }^{24}$ Université de Lille

${ }^{25}$ Texas A\&M University

${ }^{26}$ German Research Centre for Geosciences (GFZ Helmholtz Centre Potsdam)

${ }^{27}$ National Centre for Polar and Ocean Research (NCPOR)

${ }^{28}$ California Institute of Technology

${ }^{29}$ Hohai University

${ }^{30}$ Ocean University of China

${ }^{31}$ Tokyo University of Marine Science and Technology
${ }^{32}$ University of Georgia

Presenting Author: mkars@kochi-u.ac.jp

Guaymas Basin is a young marginal rift basin in the Gulf of California characterized by active seafloor spreading and rapid sediment deposition, including organic-rich sediments. International Ocean Discovery Program (IODP) Expedition 385 drilled eight sites in the Guaymas Basin in 2019. Two sites near the Sonora margin, U1549 and U1552, have been drilled close to a gas upflow pipe, with U1549 being more distal to the corresponding upflow zone than U1552. Attenuated cold seepage conditions exist at Site U1549 in the central basin with methane appearance below 25 meters below seafloor (mbsf). Hydrate was found to be present from $\sim 25 \mathrm{mbsf}$ at Site U1552. These two sites, $\sim 12 \mathrm{~km}$ apart, represent an opportunity to study the influence of gas hydrate occurrence and different geothermal gradients in shallow young organic-rich sediments $(<170 \mathrm{mbsf}$, $<0.29 \mathrm{Ma}$ ).

We present rock magnetic, geochemical, and microbiological data obtained from Sites U1549 and U1552. Coarser magnetic mineral grain size is inferred from rock magnetic measurements below the sulfate-methane transition zone (SMTZ) at Site U1549. Site U1552, however, does not seem to show this coarsening, perhaps because of the presence of gas hydrates below the shallower SMTZ. Guaymas Basin sediments are rich in reactive iron, mainly as pyrite. Iron oxides and authigenic iron sulfides are found in the sediments. XRF core scanning data show that both sites are lithologically very similar and do not seem to show any authigenic evidence of a well-marked SMTZ. Downhole variations of major elements and elemental ratios are thus comparable, solely differing by the depth where elemental changes happen. By contrast, porewater seems to characterize current environmental and diagenetic processes, especially those related to fluid and gas circulations. Differences in methane and hydrate occurrence could be due to spatial variations in fluid flow and pathways, leading to dynamic conditions at these sites. Authigenic magnetic mineralogy, mostly sensitive to biogeochemical processes at the SMTZ, would respond to fluid and gas flow variations, especially of methane. Microbiological 16S RNA analyses yield information on the microbial community in specific biogeochemical zones and on the anaerobic oxidation of methane possibly present. 